\title{
Exercise metabolism in healthy volunteers taking celiprolol, atenolol, and placebo
}

\author{
A Head, S Maxwell, M J Kendall
}

\begin{abstract}
Objective-Previous studies have shown that $\beta_{1}$ selective agents have fewer adverse effects on exercise metabolism than nonselective $\beta$ blockers, and this has been attributed to their reduced blockade of $\beta_{2}$ receptors. This study aimed at determining whether a $\beta$ blocker with partial agonist activity at $\beta_{1}$ and $\beta_{2}$ receptors (celiprolol) was better than a conventional $\beta_{1}$ receptor-blocker (atenolol) in prolonging exercise capabilities.

Methods-After four days of treatment with celiprolol $200 \mathrm{mg}$, atenolol $50 \mathrm{mg}$, or placebo, 22 healthy volunteers exercised on a treadmill for two hours at $50 \%$ of their maximal oxygen uptake. Resting heart rate and blood pressure were recorded before and after exercise. During exercise, fat oxidation, plasma free fatty acids, glycerol, glucose, and ammonia were measured together with heart rate and perceived exertion.
\end{abstract}

Results-Mean exercising heart rate was significantly lower in those taking either of the $\beta$ blockers than in those taking placebo, and significantly lower for those taking atenolol rather than celiprolol. Fat oxidation was significantly lower for those taking celiprolol (38.8 (SD 12.2)\%, P<0.01) and atenolol (36.6 (15.9)\%, $\mathrm{P}<0.01)$ compared with placebo $(45.6(14.1) \%)$. For the first $\mathbf{1 5}$ minutes of exercise, fat oxidation was significantly lower for those taking atenolol $(24.6(12.8) \%, \quad P<0.01)$ than celiprolol (29.6 (14.3)\%). The rise in plasma free fatty acids and glycerol during exercise was also significantly attenuated by both $\beta$ blockers in comparison with the rise in those taking placebo (P<0.01).

Conclusions-Both celiprolol and atenolol reduced fat oxidation compared with placebo. For the first 15 minutes of exercise fat oxidation was preserved by celiprolol, but not atenolol. This preservation of fat oxidation during the early part of exercise may confer some small benefit to patients who take $\beta$ blockers and intend to exercise regularly. However, we did not detect significant differences between atenolol and celiprolol in overall mean fat oxidation or perceived exertion in this study.

(Br F Sports Med 1997;31:120-125)

Keywords: atenolol; celiprolol; exercise; $\beta$ blockade; fat oxidation
Prolonged aerobic exercise ${ }^{1-5}$ and $\beta$ blockade $^{67}$ both have important roles in the prevention and management of cardiovascular disease. However, fatigue is a commonly reported side effect of $\beta$ blockade, and may be due to reduced cardiac output, reduced liver and muscle glycogenolysis, and reduced lipolysis, ${ }^{89}$ all of which may reduce the capacity for exercise to some degree.

As the therapeutic effects of $\beta$ blockers are due to their $\beta_{1}$ receptor blocking properties, some reduction in adipose lipolysis $\left(\beta_{1}\right.$ and $\beta_{2}$ mediated $)^{10}{ }^{11}$ must remain an unavoidable side effect of $\beta_{1}$ receptor blockade.

Celiprolol is a selective $\beta_{1}$ receptor blocker ${ }^{12}{ }^{13}$ with some partial agonist activity at both $\beta_{1}$ and $\beta_{2}$ receptors. ${ }^{14}$ The purpose of this study was to examine exercise metabolism, and particularly fat oxidation, during submaximal exercise preceded by four days' oral administration of a $\beta_{1}$ selective drug (atenolol), a $\beta_{1}$ selective drug with $\beta_{2}$ agonist properties (celiprolol), or placebo.

\section{Method}

SUBJECTS

Twenty four healthy subjects (12 male, 12 female, body mass index $\leqslant 32$ ) underwent a routine medical examination and a blood test. No abnormalities were found. Two subjects (one male, one female) were later excluded from the trial when it was discovered that they were taking previously undisclosed drugs. The remaining 22 subjects then carried out a fitness test (constant speed and increasing gradient protocol, two minute stages until exhaustion) to measure maximal oxygen uptake $\left(\mathrm{Vo}_{2} \mathrm{max}\right)$. Subjects were non-specifically trained with a $\mathrm{Vo}_{2}$ max of less than $60 \mathrm{ml} / \mathrm{kg} / \mathrm{min}$. On another day, a habituation walk was completed on a motorised treadmill at a speed and gradient producing an exercise intensity of $50 \%$ of their $\mathrm{Vo}_{2}$ max. No blood samples were taken during this stage of the trial, but heart rate, perceived exertion (category ratio scale during steady state exercise and Borg scale during incremental exercise), ${ }^{15}{ }^{16}$ subjective feeling, ${ }^{17}$ and expired air were measured every 15 minutes. Subjects also completed a mood state questionnaire ${ }^{18}$ before and after exercise. The study was approved by the South Birmingham Health Authority research ethics committee. All subjects gave written, informed consent to participate in the study.

\section{STUDY DESIGN}

The study was a double blind, randomised crossover design, with all subjects completing all conditions: celiprolol $200 \mathrm{mg}$ daily, atenolol 
$50 \mathrm{mg}$ daily, or placebo once daily. Drug treatment was for four days, with subjects taking a final dose on the morning of the fifth (trial) day. Trial days were at least seven days apart with a minimum of two days washout. A double placebo technique was used, and compliance was monitored by pill counting.

\section{EXERCISE TRIALS}

Subjects arrived at the clinical investigation unit at $\mathbf{0 8 3 0}$ on the fifth day of medication and having fasted overnight. Diet and activity patterns were recorded and replicated for each trial period. Upon arrival a final dose of the drug was taken and after 30 minutes a standardised $1 \mathrm{MJ}$ carbohydrate breakfast consumed. Subjects then rested for 90 minutes before walking for two hours on a motorised treadmill at $50 \%$ of their $\mathrm{Vo}_{2}$ max.

Every 15 minutes during the two hours' exercise, expired air was analysed to determine energy expenditure and fat and carbohydrate utilisation. Heart rate, perceived exertion, and subjective feeling were measured and recorded and $100 \mathrm{ml}$ of water given as refreshment. Blood samples $(7 \mathrm{ml})$ were taken from an indwelling venous cannula 15 minutes before exercise, at time 0 and every 30 minutes during exercise and split into vacutainers containing lithium heparin or sodium fluoride potassium oxalate. These samples were then centrifuged at $3000 \mathrm{rpm}$ for eight minutes at $4^{\circ} \mathrm{C}$, and plasma was separated and stored at $-80^{\circ} \mathrm{C}$. Further whole blood samples were used for packed cell volume and haemoglobin ${ }^{19}$ determination for calculation of plasma volume changes.

On completion of the two hours' walk, subjects continued for four two-minute stages, each at a speed and gradient producing $60 \%$, $70 \%, 80 \%$, and $90 \% \mathrm{Vo}_{2}$ max. During this phase, expired air was collected during the last minute, and heart rate, perceived exertion, and blood samples were taken during the last 15 seconds of each stage.

Fat oxidation was measured by indirect calorimetry ${ }^{20}$ (coefficient of variation (C of V) for respiratory exchange ratio (RER) after 30 minutes' exercise over the five days was $2.2 \%$, the $\mathrm{C}$ of $\mathrm{V}$ for mean percentage fat oxidation (derived from RER) over five days was $16.9 \%$ ). Glucose assay (within run $\mathrm{C}$ of $\mathrm{V}$ $2.6 \%$, between runs $4 \%$ ) was carried out by Sigma procedure No $16 \mathrm{UV},{ }^{22}$ determination of free fatty acids (within run $\mathrm{C}$ of $\mathrm{V} 2.1 \%$, between runs $5.1 \%$ ) by the WAKO chemicals NEFA C procedure, ${ }^{23}$ lactate determination (within run $\mathrm{C}$ of $\mathrm{V} 2.3 \%$, between runs $5.8 \%$ ) by the Sigma procedure $735,,^{24}$ ammonia determination (within run $\mathrm{C}$ of $\mathrm{V} 3.2 \%$ ) by the Sigma procedure $170-\mathrm{UV}^{25}$ and glycerol (within run $\mathrm{C}$ of $\mathrm{V} 1.1 \%$, between runs $6.2 \%$ ) content was determined fluorimetrically. ${ }^{26}$ Plasma concentrations during the two hour steady state exercise were corrected for plasma volume changes before analysis.

\section{STATISTICAL ANALYSES}

Data were analysed by the two factor repeated measures analysis of variance, with compari- sons between treatments adjusted using the Scheffé method. All data are presented as means (SD). Power calculations from a previous pilot study indicated that 18 complete sets of data were required to achieve a significant difference $(\alpha=0.05, \beta=0.1)$ for fat oxidation. Where data were missing-for example, because of difficulty with blood sample collection, missing cells of data were replaced with column means. The maximum number of missing cells (seven out of a possible 330 ) was for plasma ammonia data.

\section{Results}

"Treatment" refers to data collected during exercise trials performed while taking one of three treatments: celiprolol $200 \mathrm{mg}$, atenolol $50 \mathrm{mg}$, or placebo. "Time" (minutes) refers to the time of collection of sample during each trial.

AGE, WEIGHT AND $\mathrm{VO}_{2}$ MAX OF SUBJECTS

The mean age of the subjects was 22 (3.96) years, and the mean $\mathrm{Vo}_{2}$ max was 44.4 (4.70) $\mathrm{ml} / \mathrm{kg} / \mathrm{min}$, confirming the subjects as being moderately fit but not specifically endurance trained.

ENERGY EXPENDITURE DURING EXERCISE TRIALS The mean energy expenditure during the two hours' exercise trial was 3645 (993) kJ for those taking placebo, 3579 (1077) kJ for atenolol, and 3523 (913) kJ for celiprolol. There were no significant differences between treatments.

\section{HEART RATE AND BLOOD PRESSURE}

Table 1 shows the mean resting heart rates and systolic and diastolic blood pressures $(\mathrm{mmHg})$. Resting heart rate before exercise was higher for those taking celiprolol (68.7 (9.6) beats/ $\min , P<0.05)$ and lower for atenolol $(54.0$ (7.9) beats $/ \mathrm{min}, P<0.01$ ) than for placebo (65.2 (7.7) beats/min). Resting systolic pressure was also higher for celiprolol (126.1 (7.1) $\mathrm{mmHg}, \mathrm{P}<0.01)$ and lower for atenolol (116.0 (9.0) $\mathrm{mmHg}, \mathrm{P}<0.01)$ than for placebo $(121.8$ (9.4) $\mathrm{mmHg}$ ).

Figure 1 shows the heart rate at 15 minute intervals during exercise with each treatment. The mean heart rate was significantly lower for celiprolol $200 \mathrm{mg}$ (114 (7) beats/min, P<0.01) and for atenolol $50 \mathrm{mg}$ (99 (7) beats $/ \mathrm{min}$, $\mathrm{P}<0.01)$ than for placebo (132 (7) beat $/ \mathrm{min}$ ), and significantly lower for atenolol than celiprolol $(P<0.01)$.

The same relation continued during the incremental exercise period, with mean heart rate reaching 178 (9) beats/min at $90 \% \mathrm{Vo}_{2}$ max for placebo, 153 (11) beats $/ \mathrm{min}$ for celiprolol, and 141 (9) beats/min for atenolol. Heart rate remained significantly lower for both celiprolol and atenolol $(P<0.01$ at all time points) than for placebo, and significantly lower for atenolol than for celiprolol.

During rest after exercise, both celiprolol and atenolol produced a reduction in systolic and diastolic pressures, though the reduction was significantly greater with atenolol than with celiprolol. 
Table 1 Resting heart rate and systolic and diastolic blood pressures, before and after exercise for 22 subjects taking atenolol $50 \mathrm{mg}$, placebo, or celiprolol $200 \mathrm{mg}$. (Results are shown as means (SD))

\begin{tabular}{lcc}
\hline & $\begin{array}{l}\text { 15 Minutes before } \\
\text { exercise }\end{array}$ & $\begin{array}{l}\text { 15 Minutes after } \\
\text { exercise }\end{array}$ \\
\hline $\begin{array}{l}\text { Placebo } \\
\text { Heart rate } \\
\text { (beats/min) }\end{array}$ & $65.2(7.7)$ & $85.1(10.5)$ \\
$\begin{array}{l}\text { Systolic BP (mm } \\
\text { Hg) }\end{array}$ & $121.8(9.4)$ & $120.8(7.8)$ \\
$\begin{array}{l}\text { Diastolic BP (mm } \\
\text { Hg) }\end{array}$ & $66.9(7.6)$ & $65.8(7.3)$ \\
$\begin{array}{l}\text { Celiprolol 200 mg } \\
\text { Heart rate } \\
\text { (beats/min) }\end{array}$ & $68.7(9.6)^{\star}$ & $83.5(9.0) \mathrm{NS}$ \\
$\begin{array}{l}\text { Systolic BP (mm } \\
\text { Hg) }\end{array}$ & $126.1(7.1) \dagger$ & $118.4(8.1)^{\star}$ \\
$\begin{array}{l}\text { Diastolic BP (mm } \\
\text { Hg) }\end{array}$ & $66.1(5.5) \mathrm{NS}$ & $62.7(7.6) \dagger$ \\
$\begin{array}{l}\text { Atenolol 50 mg } \\
\text { Heart rate } \\
\text { (beats/min) }\end{array}$ & $54.0(7.9) \dagger \ddagger$ & $70.2(9.6) \dagger \ddagger$ \\
$\begin{array}{l}\text { Systolic BP (mm } \\
\text { Hg) }\end{array}$ & $116.0(9.0) \dagger \ddagger$ & $111.1(6.8) \dagger \ddagger$ \\
$\begin{array}{l}\text { Diastolic BP (mm } \\
\text { Hg) }\end{array}$ & $60.8(7.1) \dagger \neq$ & $58.5(7.3) \dagger \ddagger$ \\
\hline
\end{tabular}

Significantly different from placebo; ${ }^{\star} p<0.05 ; \uparrow p<0.01$

Significantly lower than celiprolol $¥ \mathrm{p}<0.01$.

\section{INDIRECT CALORIMETRY}

The contribution of fat as a fuel towards energy expenditure during the two hours' exercise trials is expressed as a percentage of the total energy expenditure during each trial (fig 2). Fat oxidation at rest was not measured. During exercise, mean fat oxidation was significantly lower for celiprolol $200 \mathrm{mg}$ (38.8 (12.2)\%, $\mathrm{P}<0.01)$ and atenolol $50 \mathrm{mg}(36.6(15.9) \%$, $\mathrm{P}<0.01)$ than for placebo (45.6 (14.1)\%). The difference in overall mean fat oxidation with celiprolol and atenolol was not significant.

After 15 minutes' exercise, fat oxidation was significantly lower for atenolol $50 \mathrm{mg}(24.6$ (12.8)\%, $\mathrm{P}<0.01)$ than for placebo $(32.2$ (12.6)\%, but the difference for celiprolol 200 mg was not significant (29.6 (14.3)\%, P = NS). After 120 minutes, fat oxidation was lower for both atenolol $(46.8(14.0) \%, \mathrm{P}<0.01)$ and celiprolol $(47.4(7.5) \%, \mathrm{P}<0.01)$ than for placebo $(57.7(12.1) \%)$. During the subsequent incremental exercise stages the RER was significantly higher for both celiprolol and atenolol than for placebo during each two minute stage. However, as this was no longer steady state exercise, calculation of fat oxidation rates from the RER was no longer valid. There were no significant differences between celiprolol and atenolol at any of the higher exercise intensities.

\section{PLASMA VOLUME CHANGES}

During exercise, plasma volume did not change significantly from resting values and there were no significant differences between treatments.

\section{PLASMA FREE FATTY ACID (FFA) AND GLYCEROL} CONCENTRATION

Figure 3 shows the plasma FFA concentration $(\mu \mathrm{mol} / 1)$. There were no significant differences between treatments at rest. As exercise progressed, there was a significant increase in plasma FFA concentration with all treatments
$(\mathrm{P}<0.01)$, confirming known responses to prolonged exercise. During exercise, there were significant differences between treatments $(P<0.01)$. After 120 minutes of exercise, plasma FFA concentration was significantly lower for celiprolol $200 \mathrm{mg}$ (493.2 (196.9) $\mu \mathrm{mol} / \mathrm{l}, \mathrm{P}<0.01)$ and atenolol $50 \mathrm{mg}(388.3$ (238.9) $\mu \mathrm{mol} / 1, P<0.01$ ) than for placebo (700.1 (245.6) $\mu \mathrm{mol} / \mathrm{l})$.

During the incremental exercise stages, the FFA concentration remained lower for both celiprolol and atenolol than for placebo $(P<0.01)$, and lower for atenolol than for celiprolol $(P<0.01)$ at 122 minutes but not at 128 minutes $(P=N S)$.

Plasma glycerol ( $\mu \mathrm{mol} / \mathrm{l}$ ) (fig 3 ) increased during exercise regardless of treatment $(P<0.01)$, confirming known responses to prolonged exercise. At rest there were no significant differences between treatments. After 120 minutes of exercise, plasma glycerol was significantly lower for both celiprolol (207.0 (80.8) $\mu \mathrm{mol} / \mathrm{l}, \mathrm{P}<0.05)$ and atenolol (195.3 (94.2) $\mu \mathrm{mol} / 1, \mathrm{P}<0.01)$ than for placebo $(244.9$ (85.8) $\mu \mathrm{mol} / \mathrm{l})$. During the incremental exercise period, and during rest after exercise, there were no significant differences between celiprolol, atenolol, and placebo $(P=N S)$. Venous blood samples proved difficult to draw during the incremental exercise period, particularly from subjects receiving active drug treatment, and therefore many samples were missed. The data are therefore from nine subjects only.

\section{PLASMA AMMONIA CONCENTRATION}

Plasma ammonia ( $\mu \mathrm{mol} / \mathrm{l}$ ) (fig 3) increased during exercise regardless of treatment $(P<0.01)$. After 60 minutes, plasma ammonia was higher for celiprolol (76.1 (39.3) $\mu \mathrm{mol} / \mathrm{l}$, $\mathrm{P}<0.05)$ and atenolol (83.5 (49.7) $\mu \mathrm{mol} / \mathrm{l}$, $\mathrm{P}<0.01)$ than for placebo $(52.8(28.7) \mu \mathrm{mol} / \mathrm{l})$. After 120 minutes, ammonia was still higher for atenolol $(97.0(59.0) \mu \mathrm{mol} / \mathrm{l}, \mathrm{P}<0.01)$ and celiprolol (87.0 (63.8) $\mu \mathrm{mol} / \mathrm{l}, \mathrm{P}<0.01)$ than for placebo (63.1 (24.5) $\mu \mathrm{mol} / \mathrm{l})$. During the incremental exercise stages, plasma ammonia was higher for atenolol at 122 minutes and 128 minutes $(P<0.01)$ than for placebo, but the difference between celiprolol and placebo was not significant.

\section{PLASMA GLUCOSE CONCENTRATION}

Plasma glucose (mmol/l) fell from rest (5.2 (1.0)) as exercise started regardless of treatment $(P<0.01)$, but euglycaemia was maintained throughout steady state $(4.9(0.48)$ at T120) and incremental exercise periods. There were no significant differences between treatments.

\section{PLASMA LACTATE CONCENTRATION}

With all treatments, plasma lactate $(\mu \mathrm{mol} / \mathrm{l})$ progressively and significantly fell from rest $(1932.0(560.0))$ during steady state exercise at $50 \% \mathrm{Vo}_{2} \max (858.0(298.0)$ at $\mathrm{T} 120$, $P<0.01)$, and there were no significant differences between treatments. During the incremental exercise stages, plasma lactate increased significantly with all treatments $(P<0.01)$, but 


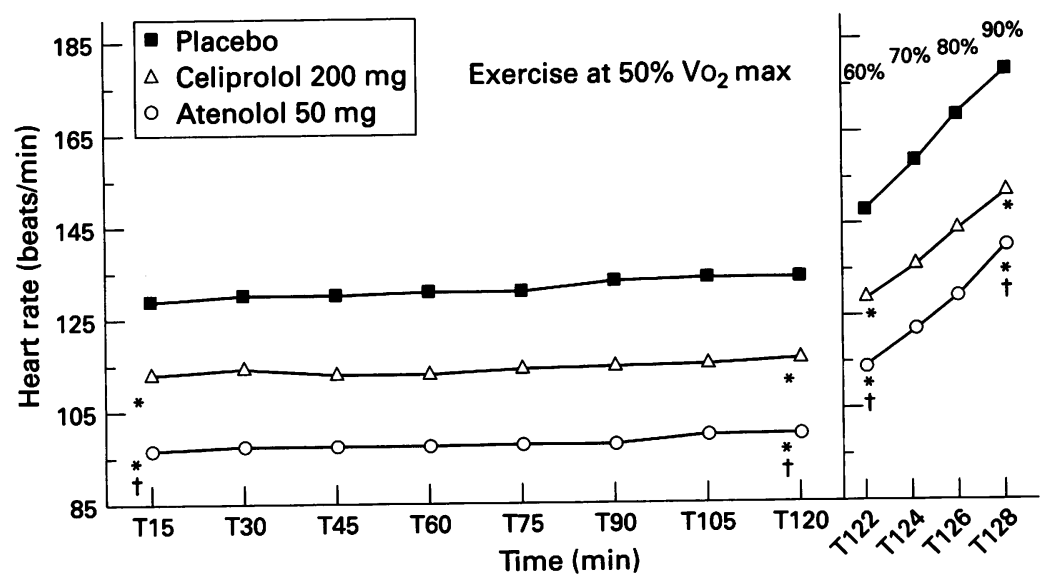

Figure 1 Heart rate during two hours' exercise at $50 \% \mathrm{VO}_{2}$ max. followed by two minutes at $60,70,80$, and $90 \% \mathrm{Vo}_{2}$ max while taking placebo, celiprolol $200 \mathrm{mg}$, atenolol $50 \mathrm{mg}$. Significantly lower than placebo ${ }^{*} P<0.01$, significantly lower than celiprolol $+P<0.01$.

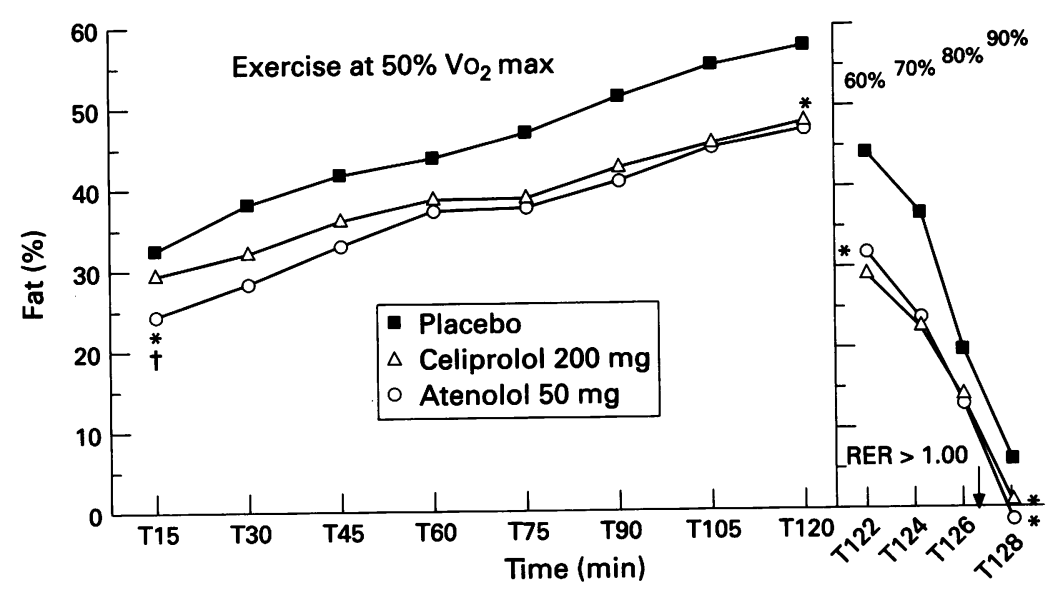

Figure 2 Fat oxidation during two hours' exercise at $50 \% \mathrm{Vo}_{2}$ max, followed by two minutes at 60,70,80, and $90 \% \mathrm{Vo}$, max while taking placebo, celiprolol $200 \mathrm{mg}$, or minutes at $60,70,80$, and $90 \% \mathrm{Vo}_{2}$ max while taking placebo, celiprolol $200 \mathrm{mg}$, or
atenolol $50 \mathrm{mg}$. Significantly lower than placebo ${ }^{*} \mathrm{P}<0.01$, significantly lower than celiprolol $+P<0.05$. RER = respiratory exchange ratio.

again there were no significant differences between treatments.

PLASMA POTASSIUM CONCENTRATION

With all treatments, plasma potassium increased significantly from rest $(4.2(0.67)$ $\mathrm{mmol} / \mathrm{l}$ ) during steady state exercise at $50 \%$ $\mathrm{Vo}_{2} \max (\mathrm{P}<0.01$ for all treatments). After 120 minutes' exercise mean plasma potassium levels on each treatment were: placebo 5.13 (0.48) $\mathrm{mmol} / 1$, celiprolol $5.14(0.40) \mathrm{mmol} / \mathrm{l}$, atenolol $5.22(0.47) \mathrm{mmol} / \mathrm{l}$, and there were no significant differences between treatments.

RATE OF PERCEIVED EXERTION (RPE) FOR LEG EFFORT

Figure 4 shows the RPE for leg effort during the two hours' exercise, which increased as exercise progressed $(P<0.01)$. After $120 \mathrm{~min}$ utes, perceived leg effort was significantly higher for celiprolol (3.6 (2.1), $\mathrm{P}<0.01)$ and atenolol (3.4 (2.1), $\mathrm{P}<0.01)$ than for placebo (2.7 (1.6)), and significantly higher for celiprolol than for atenolol $(P<0.05)$.

RPE FOR RESPIRATORY EFFORT

The RPE for respiratory effort increased as exercise progressed $(P<0.01)$, and after 120 minutes was higher for atenolol (2.5 (1.4),
$\mathrm{P}<0.05)$ and celiprolol (2.7 (1.7), $\mathrm{P}<0.01)$ than for placebo (2.1 (1.5)).

RPE FOR LEG PAIN

The RPE for leg pain increased as exercise progressed $(P<0.01)$, and after 120 minutes' exercise leg pain was higher for atenolol (2.5 (2.2), $P<0.01)$ and celiprolol (2.8 (2.3), $\mathrm{P}<0.01)$ than for placebo $(1.7(1.6))$, and higher for celiprolol than atenolol $(P<0.05)$.

FEELING SCALE

Reported feeling was from -5 (very bad) to +5 (very good) during two hours' steady state exercise at $50 \% \mathrm{Vo}_{2}$ max. Subjects generally reported feeling worse as exercise progressed $(\mathrm{P}<0.01)$, and there was a trend for subjects taking drug treatments to report that they felt worse than reported by those taking placebo (at 120 minutes: placebo $+1.6(1.2)$, celiprolol +0.5 (1.3), atenolol +1.0 (1.3)), but differences between treatments were not statistically significant.

\section{RPE DURING INCREMENTAL EXERCISE}

The RPE increased with exercise intensity $(\mathrm{P}<0.01)$. At $60 \% \mathrm{Vo}_{2} \max$ (122 minutes) $\mathrm{RPE}$ was higher for celiprolol (12.3 (2.3), $\mathrm{P}<0.01)$ than for placebo (11.4 (1.3)), but the difference between placebo and atenolol was not significant (11.9 (1.5)). At $90 \% \mathrm{Vo}_{2} \max (128$ minutes) RPE was higher for atenolol (16.5 (2.7), $\mathrm{P}<0.01)$ and celiprolol (16.5 (2.5), $\mathrm{P}<0.01)$ than for placebo $(15.6(2.1))$.

\section{Discussion}

This study compared celiprolol and atenolol at doses with comparable clinical efficacy. ${ }^{27}{ }^{28}$ In the healthy normotensive subjects in this trial, each drug had contrasting effects on the resting heart rate before exercise (when endogenous adrenergic stimulation would be minimal); celiprolol produced a slight increase and atenolol produced a decrease. Similar differences were evident in resting systolic blood pressure before exercise. The increase in resting heart rate and systolic blood pressure for patients taking celiprolol can be explained by the drug's partial agonist properties at $\beta_{1}$ and $\beta_{2}$ receptors. During recovery after exercise, when endogenous adrenergic stimulation would be higher (30 minutes after exercise, plasma adrenaline would still be twice resting values before exercise $^{29}$ ), systolic and diastolic blood pressures were reduced by both atenolol and celiprolol.

The partial agonist effect of celiprolol at $\beta_{1}$ and $\beta_{2}$ receptors may also be responsible for the observed trend toward higher resting levels of plasma FFA for those taking celiprolol (58.0 (41.8) $\mu \mathrm{mol} / \mathrm{l})$ rather than atenolol (32.8 (21.3) $\mu \mathrm{mol} / 1)$, which continued throughout exercise (fig 3). Although this trend might also be expected to be observed with plasma glycerol levels, the fact that glycerol is cleared more slowly (hepatic clearance) from plasma than FFA (rapid uptake by exercising muscle) might account for the similarity in. glycerol levels for both celiprolol and atenolol throughout exercise. 

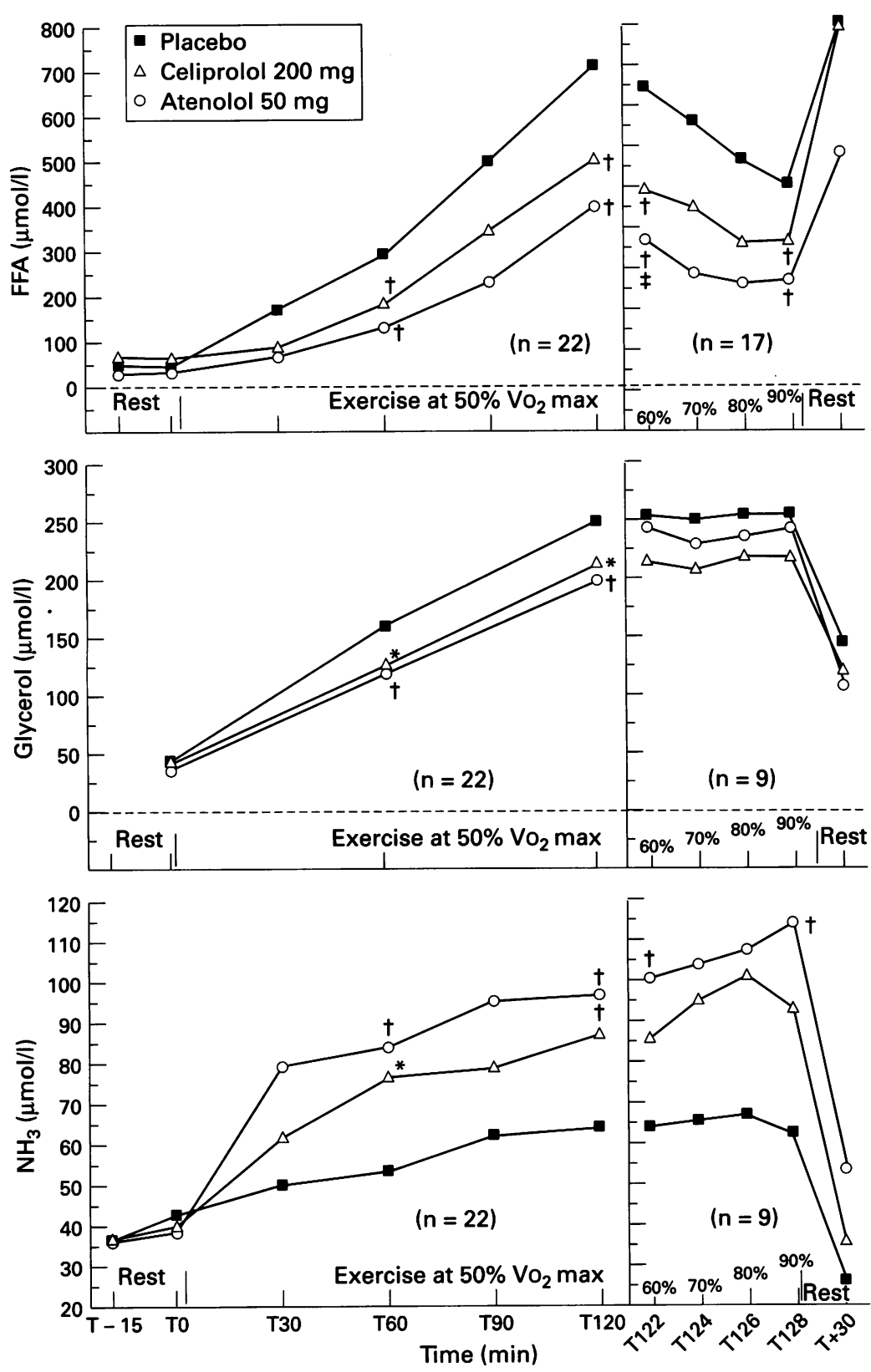

Figure 3 Plasma free fatty acid (FFA), glycerol, and ammonia $\left(\mathrm{NH}_{3}\right)$ during two hours' exercise at $50 \% \mathrm{VO}_{2}$ max, followed by two minutes at $60,70,80$, and $90 \% \mathrm{VO}_{2}$ max, while taking placebo, celiprolol $200 \mathrm{mg}$, atenolol $50 \mathrm{mg}$. Significantly lower than placebo ${ }^{*} P<0.05,+P<0.01$ significantly lower than celiprolol $\neq P<0.01$.
Both celiprolol and atenolol significantly reduced fat oxidation compared with placebo. For the first 15 minutes of exercise, fat oxidation with celiprolol and placebo was not significantly different, but was significantly lower with atenolol than with placebo. There was a trend for atenolol to reduce fat oxidation more than celiprolol over the first hour, but the difference was not significant.

The very low level of resting mean plasma FFA for placebo (53 (48) $\mu \mathrm{mol} / \mathrm{l})$ might have been a response to the carbohydrate meal before exercise. Plasma FFA and plasma glycerol (fig 3) concentrations were not significantly different between celiprolol and atenolol for the same early period of exercise. In fact, for the first 30 minutes of exercise, plasma FFA and plasma glycerol values were almost identical for both drug treatments. Therefore it is unlikely that the early differences noted in the rates of fat oxidation between celiprolol and atenolol are due to different effects on adipose lipolysis and plasma FFA concentration. Possibly, changes in intramuscular lipolysis may be responsible.

Cleroux and Leenen have suggested that intramuscular lipolysis is under $\beta_{2}$ receptor control. ${ }^{11}$ We believe that the higher rate of fat oxidation with celiprolol during the early part of exercise is due to the $\beta_{2}$ receptor stimulation, which increases the rate of intramuscular lipolysis during the onset of exercise when endogenous adrenergic stimulation is low. However, possibly, the $\beta_{2}$ agonist effect in this study was minimal, and a higher dose of 400 mg might have increased $\beta_{2}$ receptor stimulation, producing greater changes in fat metabolism. A future study might address this point. The maintenance of fat oxidation delays the depletion of glycogen stores, thereby reducing any metabolic basis for premature fatigue. The plasma ammonia data appear to support this hypothesis, as there is a trend for plasma ammonia to be higher for atenolol during steady state exercise, and during the incremental exercise period.

The origins of the increased plasma ammonia during exercise of moderate intensity are still debated, but it is well known that plasma ammonia rises with increased exercise intensity and duration, and with depleted glycogen stores, ${ }^{3031}$ and may be a useful marker of metabolic stress. There are two possible explanations for the observed increases in plasma ammonia during prolonged exercise. One is that branch chain amino acid oxidation increases, ${ }^{32}$ and the other (perhaps more likely) is that when substrate supply to exercising muscle fat in this case) is restricted, degradation of ADP to AMP and IMP occurs, producing ammonia by the action of AMP deaminase. ${ }^{31}{ }^{33} \beta$ Blockade, ${ }^{34}$ and particularly non-selective $\beta$ blockade, ${ }^{35}$ significantly increases plasma ammonia during exercise of moderate intensity, suggesting that metabolic stress is increased in those exercising and taking $\beta$ blockers.

In previous studies, reduced fat oxidation correlated well with increased perceived exertion. ${ }^{34}{ }^{35}$ However, in this study perceived
Figure 4 Rate of perceived exertion (RPE) for leg effort during two hours' exercise at $50 \% \mathrm{VO}_{2}$ max while taking placebo, celiprolol $200 \mathrm{mg}$, or atenolol $50 \mathrm{mg}$. Significantly higher than placebo $* P<0.01$, significantly higher than atenolol $+P<005$. 
exertion for leg effort and leg pain during steady state exercise was higher for celiprolol than for atenolol despite fat oxidation being better maintained by celiprolol. The reason for this disparity is unclear.

In conclusion, both atenolol and celiprolol attenuated the normal rise in fat oxidation during prolonged exercise. Any reduction or delay in fat oxidation places increased demand on glycogen stores, and could lead to a reduction in exercise capacity. Celiprolol appeared to maintain fat oxidation at least during the first 15 minutes of exercise. Further investigation of $\beta$ blockers with $\beta_{2}$ agonist properties is warranted.

This study was supported by Rhone Poulenc Rorer.

1 Secretary of State for Health. The health of the nation. A strategy for health in England. London: HMSO, 1992:46-7, egy for 4 .

2 Blair SN, Koho HW III, Paffenbarger RS Jr, Clark DG, Cooper KH, Gibbons LW. Physical fitness and all cause mortality. A prospective study of healthy men and women fAMA 1989;262:2395-401.

3 Morris IN, Clayton DG, Everitt MG, Semmence AM, Burgess EH. Exercise in leisure time: coronary attack and death rates. Br Heart $\mathcal{1}$ 1990;63:325-34.

4 Shaper AG, Wannamethee G. Physical activity and ischaemic heart disease in middle-aged British men. Br Heart $\mathcal{f}$ 1991;66:384-94.

5 Chandrashekhar Y, Anand IS. Exercise as a coronary protective factor. Am Heart $\mathcal{f} 1991$; 122:1723-36

6 Wikstrand J, Warnold I, Olsson G, Tuomilehto J, Elmfeld $D$, Berglund G, et al. Primary prevention with metoprolo in patients with hypertension. Mortality results from in patients with hypertension. Mortality

7 Olssen G, Wikstrand J, Warnold I, Manger Cats V, McBoyle Olssen G, Wikstrand J, Warnold I, Manger Cats V, McBoyle
$\mathrm{D}$, Herlitz J, et al. Metoprolol-induced reduction in $\mathrm{D}$, Herlitz J, et al. Metoprolol-induced reduction in post-infarction mortality: pooled results from five

8 Trapp-Jensen J, Clausen JP, Noer I, Larsen OA, Krogsgaard AR, Christiansen NJ. The effects of beta-adrenocepto blockers on cardiac output, liver blood flow and skeletal muscle blood flow in hypertensive patients. Acta Physio Scand 1976;440(suppl):27.

9 Juhlin-Dannfeldt A, Terblanch SE, Fell RD, Young JC, Holloszy JO. Effects of $\beta$-adrenergic receptor blockade on glycogenolysis during exercise. $\mathcal{F}$ Appl Physiol 1982;53:54954 .

10 Smith U. Adrenergic control of lipid metabolism. Acta Med Scand 1983;672(suppl):41-7.

11 Cleroux J, Leenen FH. Effects of beta blockade on muscle metabolism during prolonged exercise. A short review. $A m$ m Hypertens $1988 ; 1: 290 \mathrm{~S}-4 \mathrm{~S}$.

12 Pittner H. Pharmacodynamic actions of celiprolol, a cardioselective beta-receptor blocker. Arzneimittelforschung

13 Louis WJ, Drummer OH, Fung LH. Pharmacology of celiprolol. Cardiovascular drugs and therapy 1990;4:1281-6.

4 Wheeldon NM, McDevitt DG, Lipworth BJ. Selectivity of antagonist and partial agonist activity of celiprolol in normal subjects. Br f Clin Pharmacol 1992;34:337-43.
15 Borg GAV. Physical performance and perceived exertion. Lund, Sweden: Gleerup, 1962:1-62.

16 Borg GAV. Perceived exertion as an indicator of somatic stress. Scand f Rehabil Med 1970;2:92-8.

17 Hardy HJ, Rijesky WJ. Not what but how one feels: the measurement of effect during exercise. fournal of Sports Psychology 1989;11:304-17.

18 McNair DM, Lorr M, Droppleman LF. EDITS manual for the profile of mood states (POMS). San Diego, CA Educational and Industrial Testing Service, 1971.

19 Harrison $\mathrm{MH}$, Edwards RJ. Measurement of change in plasma volume during heat exposure and exercise. Avia Space Environ Med 1976;47:1038-45.

20 Wilmore J, Costill DL. Adequacy of the Haldane transformation in the computation of exercise $\mathrm{VO}_{2}$ in man. $\mathcal{F} A p p$ Physiol 1973;35:85-9.

21 Consolazio C, Johnson R, Pecora L. Physiological measurements of metabolic functions in man. New York: McGrawHill, 1963.

22 Stein MW. D-Glucose: determination with hexokinase and glucose-6-phosphate dehydrogenase. In: Bergmeyer HU, ed. Methods of enzymatic analysis. New York: Academic ed. Methods of enzy

23 Mulder C, Schouten JA, Popp-Snijders C. Enzymatic colorimetric test for in vitro assay of free fatty acids in serum and plasma. 7 Clin Chem Biochem 1983;21:823-7.

24 Hohorst HJ. Enzymatic determination of lactic acid. In Bergmeyer HU, ed. Methods of enzymatic analysis. New York: Academic Press, 1963:266.

25 Conn HO. Blood ammonia. In: Meites S, ed. Standard meth ods of clinical chemistry. Vol 5. New York: Academic Press, 1965

26 Bergmeyer HU. Glycerol. Methods of enzymatic analysis. Verlag Chemie 1974;3:1404-8.

27 Stumpe K, Kolloch R, Mathieu M, Capone P. A comparison of celiprolol and atenolol in the treatment of hypertension: a placebo controlled double blind study. Br f Clin Pract 1985;39(suppl 40):73-5.

28 Silke B, Rosenthal F, Taylor S. A randomised double blind study of celiprolol compared to atenolol in mild and moderate hypertension. F Cardiovasc Pharmacol 1986;8(supp 4):122-6.

29 Lundborg P, Astrom H, Bengtsson C, Fellenius E, Von Schenck H, Svensson L, et al. Effect of $\beta$-adrenoceptor blockade on exercise performance and metabolism. Clin $\mathrm{Sci}$ 1981;61:29-305.

30 Buono MJ, Clancy TR, Cook JR. Blood lactate and ammonium ion accumulation during graded exercise in humans. f Appl Physiol 1984;57:135-9.

31 Broberg S, Sahlin K. Adenine nucleotide degradation in human skeletal muscle during prolonged exercise. $\mathcal{F} A p p$ Physiol 1989;67:116-22.

32 MacLean DA, Spriet LL, Hultman E, Graham TE. Plasma and muscle amino acid and ammonia responses during prolonged exercise in humans. 7 Appl Physiol 1991;70: 2095-103.

33 Sahlin $\mathrm{K}$ Areskog NH, Haller RG, Henriksson KG, Jorfeld $\mathrm{L}$, Lewis SF. Impaired oxidative metabolism increases adenine nucleotide breakdown in McArdles disease. $\mathcal{F} A p p$ Physiol 1990;69:1231-5.

34 Head A, Maxwell S, Kendall M J, Eagles C. Exercise metabolism in healthy volunteers taking atenolol, high and low doses of metoprolol $\mathrm{CR} / \mathrm{ZOk}$, and placebo. $\mathrm{Br} F \mathrm{Cl}$ Pharmacol 1994;38:S499-504.

35 Head A, Kendall MJ, Maxwell S. Exercise metabolism during one hour of treadmill walking while taking high and low doses of propranolol, metoprolol, or placebo. Clin Cardio 1995;18:335-40. 